\title{
THE ROLE AND DUTIES OF DIRECTORS IN THE PROMOTION OF CORPORATE GOVERNANCE: A SOUTH AFRICAN PERSPECTIVE
}

\author{
Monray Marsellus Botha \\ BLC LLB LLM BCom(Hons) \\ Senior Lecturer, Department of Mercantile Law \\ University of Pretoria
}

\section{SUMMARY}

Owing to global changes in the field of corporate governance and corporate law reform in South Africa, corporate governance has become an important aspect of the way in which corporations are doing business. Corporate governance is the collection of law and practices that is grounded in the fiduciary duties of directors. It regulates the conduct of those in control of the corporation. An important aspect of corporate governance is the establishment of structures and processes that enable directors to discharge their legal responsibilities. This article investigates corporate governance principles in South Africa and explores the importance of the role and duties of directors in the promotion of corporate governance principles.

\section{INTRODUCTION}

Corporate governance is not a new or unique phenomenon in South Africa. Developments in corporate governance jurisprudence have taken place worldwide, especially in the United States, the United Kingdom and Australia. South Africa published the first King Report in 1994, ${ }^{1}$ which was followed by the King Report on Corporate Governance for South Africa in 2002. ${ }^{2}$ When taking cognisance of King II it must be emphasised that the 19th century was the century of the entrepreneur in that the foundations of what corporations currently look like were laid down. Management became the focus in the 20th century. The focus in the 21 st century is on governance of corporate entities not only in South Africa but worldwide.

Owing to changes in international governance trends and the need to reform South African company law, the third report on Corporate Governance in South Africa of $2009^{4}$ was needed because of the highly anticipated Companies Act 71 of $2008 .^{5}$ This was a result of the Department

The King Report on Corporate Governance (hereinafter "King I").

Hereinafter "King II".

King II 14 par 24.

Hereinafter "King III".

Hereinafter "the Companies Act". 
of Trade and Industry's policy paper ${ }^{6}$ which envisaged the development of a "clear, facilitating, predictable and constantly enforced governing law". According to the policy paper competitiveness and development of the South African economy should be promoted by company law. This should be done by means of: (1) encouraging entrepreneurship and enterprise diversity through simplifying the formation process of companies and reducing the associated costs; (2) promoting innovation and investment in markets and companies through a predictable and effective regulatory environment and flexibility in the formation and the management of companies; (3) promoting the efficiency of companies and their management; (4) encouraging transparency and high standards of corporate governance; and (5) ensuring compatibility and harmonisation with international best practices.

\section{REGULATORY FRAMEWORK OF CORPORATE GOVERNANCE}

Governance can be described as "traditions and institutions by which authority in a country is exercised for common good". ${ }^{8}$ According to the United Nations Commission for Global Governance, governance entails how common affairs are managed by individuals and private and public institutions. It must also address incompatible or different interests on a continuous basis. Not only does compliance form an important part of this process but it also consists of perceived or agreed informal arrangements between people and institutions.

There is no generally accepted definition of the concept "corporate governance". When dealing with this concept the key to a proper understanding thereof lies in the distinction between corporate law and corporate finance law. ${ }^{10}$ Three different groups are formally recognised in terms of corporate law, namely, shareholders, directors and officers of a company. From this, rights and obligations are obtained, imposed and distributed among the different role-players. ${ }^{11}$ When money is raised for the company for the utilisation in its business operations, corporate finance law becomes relevant. The law of corporate finance is important especially when it comes to pre-incorporation contracts, the incorporation and commencement of business of the company, financing of shares, share capital, et cetera. ${ }^{12}$ It can therefore be said that corporate governance addresses the entire span of responsibilities to stakeholders of the company, such as customers,

6 South African Company Law for the 21st Century - Guidelines for Corporate Law Reform (GG 26493 of 2004-06-23) (hereinafter "DTI Policy Paper").

DTI Policy Paper 9.

8 Kaufman, Kray and Lobaton "Governance Matters and Aggregating Governance Indicators" 1999 Paper Series No 2195 World Bank Research Working Conference.

9 Commission on Global Governance Our Global Neighborhood (1995) 2.

10 Aka "Corporate Governance in South Africa: Analyzing the Dynamics of Corporate Governance Reforms in the 'Rainbow Nation'” 2007 North Carolina Journal of International Law and Commercial Regulation 237.

11 Ibid.

12 Aka 2007 North Carolina Journal of International Law and Commercial Regulation 238. 
employees, shareholders, suppliers and the community at large. ${ }^{13}$ According to the Cadbury Report on Corporate Governance in the United Kingdom, corporate governance is concerned with creating a balance between economic and social goals in order to align as far as possible the different interests of individuals, corporations and society. ${ }^{14}$ Corporate governance can thus be defined as "the collection of law and practices, grounded in fiduciary duties and their application, that regulates the conduct of those in control of the corporation, and the means through which a variety of countries provide legal basis for corporations while preserving, to some extent, authority to control abuses of these business organizations". ${ }^{15}$ It must therefore be pointed out that corporate governance for the most part involves the establishment of systems that enable directors to discharge their legal responsibilities. ${ }^{16}$

The South African corporate governance and corporate law regime originated in the United Kingdom. The current framework of South African company law has its foundations in English law and is consolidated in the Companies Act 61 of 1973 . The various King reports on corporate governance, other legislative developments and the South African and other global economies necessitated a need for reform since the early 1990s. ${ }^{17}$ Developments in legislation had a profound and direct effect on good and corporate governance in South Africa. ${ }^{18}$ This link between governance principles and law can be summarised as follows:

"Good governance is not something that exists separately from the law. It is entirely inappropriate to unhinge governance from the law ... In assessing appropriate conduct, a court will take into account all relevant circumstances, including what is regarded as the normal or usual practice in the particular situation ... Criteria of good governance, governance codes and guidelines will be relevant in the determination of what is regarded as an appropriate standard of conduct. The more established certain governance practices become, the more likely a court would regard conduct that conforms with these practices as meeting the required standard of care ... Consequently, any failure to meet a recognised standard of governance, albeit not legislated, may render a board or individual director liable at law."

Some corporate governance approaches do not merely focus on the protection of shareholder interests but also on the protection of stakeholder

13 Hurst "Corporate Ethics, Governance and Social Responsibility: Comparing European Business Practices to Those in the United States" Spring 2004, a study conducted for the Business and Organizational Ethics Partnership: Markula Center for Applied Ethics, Santa Clara University http://www.scu.edu 6 (accessed 2009-06-07).

14 King II 6.

15 Aka 2007 North Carolina Journal of International Law and Commercial Regulation 238.

6 King III 10

7 DTI Policy Paper 3.

1 The Constitution of the Republic of South Africa, 1996; the Labour Relations Act 66 of 1995; the Basic Conditions of Employment Act 75 of 1997; the Employment Equity Act 55 of 1998; the Insider Trading Act 135 of 1998; the Public Finance Management Act 1 of 1999; the Protected Disclosures Act 26 of 2000; the Promotion to Access to Information Act 2 of 2000 the Promotion of Administrative Justice Act 3 of 2000; the Promotion of Equality and Prevention of Unfair Discrimination Act 4 of 2000; the Prevention and Combating of Corrupt Activities Act 12 of 2004; and the Securities Services Act 36 of 2004 to mention but a few.

19 King II 10. 
interests. In this regard three approaches can be highlighted. Firstly, the socalled "shareholder system" in terms of which shareholders are the focus of corporate activity; secondly, the "enlightened shareholder value" in terms of which directors should in appropriate circumstances need to ensure productive and long-term relationships with stakeholders but with shareholders' interests retaining primacy; and thirdly, the "pluralist approach" in terms of which a balancing of the shareholders' interests with those of others committed to the company must take place..$^{20}$ In light of the "enlightened shareholder value approach" the following theoretical underpinnings can be highlighted: (i) shareholders who invested capital in the company are entitled to profits after other claims, (ii) the shareholders, as residual claimants of whatever is left after all other claims have been paid, are the best positioned to police the efficiency of the company; and (iii) the survival and economic success of a company will deliver social benefits to many stakeholder constituencies, which will not be delivered if the company is a financial failure. ${ }^{21}$ In terms of the Anglo-American shareholder system the objective of corporate governance is to incorporate control mechanisms and incentives to capitalise on the return on equity investment and where ownership and control are separated. ${ }^{22}$ The stakeholder system is typical to countries like Germany, Japan and France. According to this theory the interests of the corporation's other stakeholders such as employees, customers, suppliers, creditors and the government are considered. ${ }^{23}$ The interests of various stakeholder groups in the context of the corporation as a "social institution" should be enhanced and protected. ${ }^{24}$ Corporate governance from the stakeholder perspective thus entails a system where a balance is achieved between the interests of the various stakeholders of the corporation. ${ }^{25}$ From this perspective it is a complicated bargaining process involving all the stakeholders in the corporation. ${ }^{26}$ Trust is thus created between the company and all its internal and external stakeholders. Integrity, transparency and accountability are essential characteristics for effective and responsible leadership. ${ }^{27}$ This is in line with the spirit of King III with reference to the so-called stakeholder-inclusive approach. The latter approach recognises the importance of stakeholders in the achievement and long-term growth of companies. Stakeholders can be any group affected by the company or its reputation or who can affect the company or its reputation such as creditors, suppliers, customers, the media, investors, etcetera. Annual general meetings and cooperation with trade union representatives should as formal processes be considered, but must not be the only form of

20 DTI Policy Paper 22-23; Esser "The Enlightened-shareholder-value Approach versus Plurism in the Management of Companies" 2005 Obiter 719-721; and Esser "Shareholder Protection: The Position of Employees" 2007 THRHR 410-411.

21 DTI Policy Paper 20-21.

22 Fauver and Fuerst "Does Corporate Governance Include Employee Representation? Evidence from German Corporate Boards" 2006 Journal of Financial Economics 674.

23 Ibid.

24 Rossouw "Balancing Corporate and Social Interests: Corporate Governance Theory and Practice" November 2008 3(1) African Journal of Business Ethics 29.

25 Ibid.

26 Stiglitz "Quis Custodiet Ipsos Custodes?" 1999 42(6) Challenge 44.

27 King II 55 par 28. 
contact because informal processes such as direct contact, websites, press releases or advertising should also be considered. Because communication is important the company should stimulate dialogue with all the stakeholders to enable it to enhance or restore confidence with stakeholders, remove tension between the company and stakeholders or relieve pressure. Companies should also offer opportunities in order to align their expectations, ideas and opinions with that of stakeholders on certain issues. ${ }^{28}$

\section{DUTIES OF DIRECTORS}

The duties of directors have been a problematic area of company law. These duties, however, remain important because they play a role in ensuring the promotion of corporate governance principles. ${ }^{29}$ The Companies Act 61 of 1973 did not contain clear rules regarding the duties and liabilities of directors and corporate governance. The regulation of these aspects was largely left to King II and the common law. ${ }^{30}$ Directors' common-law fiduciary duties require them to exercise their powers bona fide and for the benefit of the company. In addition, they have the duty to display reasonable care and skill in carrying out his office. ${ }^{31}$ Director's fiduciary duties entail that they act in the best interests of the company, ${ }^{32}$ avoid conflicts, do not take corporate opportunities or secret profits, do not fetter their votes and use their powers for the purpose conferred and not for a collateral purpose. ${ }^{33}$ The duty of care, skill and diligence entails that "directors must manage the business of the company as a reasonably prudent person would manage his own affairs". ${ }^{34}$ The Companies Act now contains provisions dealing with directors' general duties that are comparable to the common-law duties of directors. ${ }^{35}$ The standards of directors' conduct are covered by section 76 of the Companies Act. Section 76(3) provides as follows:

"[A] director of a company, when acting in that capacity, must exercise the powers and perform the functions of director -

(a) in good faith and for a proper purpose;

(b) in the best interests of the company; and

(c) with the degree of care, skill and diligence that may reasonably be expected of a person -

(i) carrying out the same functions in relation to the company as those carried out by that director; and

(ii) having the general knowledge, skill and experience of that director."

\footnotetext{
King II 110-111.

Mongalo Corporate Law and Corporate Governance (2003) 158

30 Davis, Cassim, Geach, Mongalo, Butler, Loubser, Coetzee and Burdette Companies and other business structures in South Africa (2009) 101.

31 Benade, Henning, Du Plessis, Delport, De Koker and Pretorius Entrepreneurial law (2008) 130.

32 Mongalo 160 compares this duty to that between a guardian of a ward, an agent of the principal, an attorney to a client and a partner to a co-partner.

King III 12

34 King III 11; and Benade et al 131.

35 Esser and Du Plessis "The Stakeholder Debate and Directors' Fiduciary Duties" 2007 SA Merc LJ 347.
} 
Section 76(2) further provides that:

"A director of a company must -

(a) not use the position of director, or any information obtained while acting in the capacity of a director -

(i) to gain an advantage for the director, or for another person other than the company or a wholly-owned subsidiary of the company; or

(ii) to knowingly cause harm to the company or a subsidiary of the company; and

(b) communicate to the board at the earliest practicable opportunity any information that comes to the director's attention, unless the director -

(i) reasonably believes that the information is -

(aa) immaterial to the company; or

(bb) generally available to the public, or known to the other directors;

or

(ii) is bound not to disclose that information by a legal or ethical obligation of confidentiality."

A director stands in a fiduciary relationship with his company with the result that he has a duty to act in good faith towards the company. This means that he must exercise his powers as director for the benefit of the company and avoid a conflict between his own interests and those of the company. ${ }^{36}$ In Cyberscene Ltd $v$ i-Kiosk Internet and Information (Pty) Ltd ${ }^{37}$ the court emphasised the fact that a fiduciary duty exists between a company and its directors. The court also stated that even non-executive directors have this fiduciary relationship towards the company. ${ }^{38}$ The court confirmed that the fiduciary duty of directors can be remedied by means of an interdict. This duty has a more far-reaching effect on senior employees and directors than on junior employees because the latter group's duty only extends to confidential confirmation and trade secrets. The fiduciary duty is therefore owed by senior management and this common-law duty extends even after a director's appointment has come to an end. ${ }^{39}$

Benade et al 130

20003 SA 806 (C).

38 Cyberscene Ltd v i-Kiosk Internet and Information (Pty) Ltd supra 820f. In Howard $v$ Herrigel 19912 SA 679 (A) 678 the court held as follows: "In my opinion it is unhelpful and even misleading to classify company directors as 'executive' or 'non-executive' for purposes of ascertaining their duties to the company or when any specific or affirmative action is required of them. No such distinction is to be found in statute. At common law, once a person accepts an appointment as director, he becomes fiduciary in relation to the company and is obliged to display the utmost good faith towards the company and in his dealings on its behalf. That is the general rule and its application to any particular incumbent of the office of director must necessarily depend on the facts and circumstances of each case ... However, it is not helpful to say of a particular director that, because he was not an 'executive director', his duties were less onerous than they would have been if he were an executive director. Whether the inquiry be one in relation to negligence, reckless conduct or fraud, the legal rules are the same for all directors." See also Symington $v$ Pretoria-Oos Privaat Hospitaal Bedryfs (Pty) Ltd [2005] 4 All SA 403 (SCA) 411.

39 Cyberscene Ltd $v$ i-Kiosk Internet and Information (Pty) Ltd supra 820g-I; Atlas Organic Fertilizers (Pty) Ltd v Pikkewyn Ghwano (Pty) Ltd 19812 SA 173 (T) 198d-h; Sibex Construction (SA) (Pty) Ltd v Injectaseal CC 19882 SA 54; Daewoo Heavy Industries (SA) Ltd v Banks [2004] 2 All SA 530 (C) 533c-e; and Da Silva v CH Chemicals (Pty) Ltd 20086 SA 620 (SCA) 628f-g. 
According to Delport ${ }^{40}$ the common-law principle is that "all contracts between a director and the company are voidable at the instance of the company, based on the principle that there shall be no conflict of interest and also, flowing from that, that a director cannot make a 'secret profit'". This is called the "no-profit" rule. Delport is also of the view that the summary in Phillips $v$ Fieldstone Africa (Pty) Ltd ${ }^{41}$ should suffice but it is uncertain whether this rule will still apply because the statutory provisions do not expressly exclude it. In this case the court held that the rule is strict and leaves little room for exceptions. It covers not only actual conflicts but also those that are in real terms possible. A fiduciary will have limited defences to his avail. Only the free consent of the principal after full disclosure will suffice. The court added:

"Because the fiduciary who acquires for himself is deemed to have acquired for trust, once proof of a breach of a fiduciary duty is adduced it is of no relevance that (1) the trust has suffered no loss or damage; (2) the trust could not itself have made use of the information, opportunity etc or probably would not have done so; (3) the trust, although it could have used the information, opportunity, etc has refused it or would do so; (4) there is no privity between the principal and the party with whom the agent or servant is employed to contract business and the money would not have gone into the principal's hands in the first instance; (5) it was no part of the fiduciary's duty to obtain the benefit for the trust; or (6) the fiduciary acted honestly and reasonably."

One of the principles of good governance is that directors must act in the best interest of the company. King III now specifically provides for the "apply or explain" principle that must be applied by directors when acting on behalf of the company. According to this principle directors must act in good faith in that they must be honest, act in the best interests of the company, not receive secret profits and must promote the purpose for which the company was established. In an "apply or explain" regime:

"the board of directors, in its collective decision making, can conclude that to follow a practice recommended in a code would not, in the particular circumstances pertaining at the time in regard to an issue, be in the best interests of the company and apply another practice. It must explain the practice it applies other than the recommended one and the reasons for applying it. Hindsight is a perfect judge on whether the board's determination

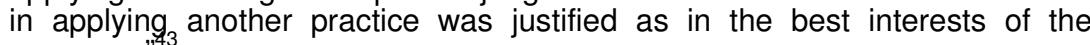
company.

What must be noted here is that in terms of King II the "comply or explain" principle was applied. It is, however, unclear what should be explained, if not complied with. It is also unclear whether King II merely laid down suggestions or expectations. ${ }^{44}$ What is important to note, however, is the fact that King II was only voluntary. The same applies to the "apply or explain" principle in King III. It must also be noted that self-regulatory codes such as

The Companies Act Manual (2009) 60.

[2004] 1 All SA 150 (SCA).

Phillips v Fieldstone Africa (Pty) Ltd supra 160-161.

King III 8.

44 Esser Recognition of Various Stakeholder Interests in Company Management (Unpublished Doctoral Thesis 2008) 295 
the various King Reports contain guidelines or recommendations of best practice and are therefore voluntary. ${ }^{45}$ King III is therefore only applicable to JSE listed companies and companies in terms of the Public Finance Management Act. They are the only companies that need to comply with the recommendations in King III with regard to the "apply or explain" principle. Other types of companies need not comply with King III.

The duty of care, skill and diligence is another important duty of directors. A good illustration of how this duty works can be found in Fisheries Development Corporation of SA Ltd $v$ Jorgensen. ${ }^{46}$ In this case the court stated the following:

- A considerable degree of the nature of the company's business and of any particular obligations assumed by or assigned to a director must be taken into account when dealing with a director's duty of care and skill. A distinction must also be drawn between the so-called full-time or executive director, and the non-executive director. An executive director participates in the day-to-day management of the company's affairs or of a portion thereof whereas a non-executive director has not undertaken any special obligation and is not bound to give constant consideration to the affairs of the company. The latter's duties are of an irregular nature in that he can be required to attend periodic board meetings, and any other meetings which may require his attention. He is not, however, bound to attend all such meetings, though he ought to whenever he is reasonably able to do so. He can also call for further meetings if he believes that they are reasonably necessary.

- His duties and qualifications are not listed as being equal to those of an auditor or accountant nor is he required to have special business acumen or expertise, or ability or intelligence, or experience in the business of the company. He is nevertheless expected to exercise the care which can reasonably be expected of a person with his knowledge and experience. $\mathrm{He}$ is not liable for mere errors of judgment.

- A director can delegate any duty that may properly be left to some other official. When doing so a director is, in the absence of grounds for suspicion, justified in trusting that official to perform such duties honestly. $\mathrm{He}$ is entitled to rely upon and accept the judgment, information and advice of the management, unless he has proper reasons for querying it. $\mathrm{He}$ is also not bound to examine entries in the company's books, however; he should not accept information and advice blindly. When he accepts information and advice, he is entitled to rely on it, but he should give due consideration and exercise his own judgment in the light thereof. ${ }^{47}$

If a director is in breach of his duty of care, skill and diligence he is liable to the company in delict for damages and if, in addition, a contract exists between the director and his company he is also guilty of breach of

45 Esser (Unpublished Doctoral Thesis 2008) 290.

$46 \quad 19804$ SA $156(\mathrm{~W})$

47 Fisheries Development Corporation of SA Ltd $v$ Jorgensen supra 165g-166e. 
contract. ${ }^{48}$ The standard of care is a "mixed objective and subjective test, in the sense that the minimum standard is that of a reasonably prudent person, but a director who has greater skills, knowledge or experience than the reasonable person must give to the company the benefit of those greater skills, knowledge and experience". ${ }^{49}$ Mongalo is of the view that no clear borderline exists between the fiduciary duty and the duty of care and skill and that overlapping can exist. If such overlapping does indeed exist it is known as the "business judgment rule". 50 According to McLennan ${ }^{51}$ the objective-subjective test can be found in sections 76(3)(c)(i) and (ii) of the Companies Act. Subsection (c)(i) contains the objective test and (c)(ii) the subjective one. McLennan adds that this objective-subjective test is compatible with the so-called "business judgment rule". ${ }^{52}$ Bekink $^{53}$ is of the opinion that the subjective standards of "the general knowledge, skill and experience of that director" might overshadow the objective standards which might confuse the courts in the interpretation of the director's duties. The solution, however, lies in the fact that the objective test may be a base-line standard before the subjective elements are considered. ${ }^{54}$ The statutory "business judgment rule" can be found in section 76(4). This section adds that:

"in respect of any particular matter arising in the exercise of the powers or the performance of the functions of director, a particular director of a company -

(a) will have satisfied the obligations of subsection (3)(b) (in the interest of the company) and (c) (care and skill) if -

(i) the director has taken reasonably diligent steps to become informed about the matter;

(ii) either -

(aa) the director had no material personal financial interes $\mathrm{t}^{55}$ in the subject matter of the decision, and had no reasonable basis to know that any related person had a personal financial interest in the matter; or

(bb) the director complied with the requirements of section 75 with respect to any interest contemplated in subparagraph (aa); and

(iii) the director made a decision, or supported the decision of a committee or the board, with regard to that matter, and the director had a rational

48 Cilliers and Benade Corporate law (2000) 148.

49 King III 11-12.

50 Mongalo 170; and Havenga "The Business Judgment Rule - Should we Follow the Australian Example?" 2000 SA Merc LJ 25.

51 McClennan "Directors' Fiduciary Duties and the 2008 Companies Bill" 2009 TSAR 186; and Meskin et al Henochsberg on the Companies Act 1 (2009) 462.

52 Delport 59.

53 Bekink "An Historical Overview of the Director's Duty of Care and Skill: From the Nineteenth Century to the Companies Bill of 2007" 2008 SA Merc LJ 111.

54 lbid.

55 A "personal financial interest" is defined in s 1 of the Companies Act as "a direct material interest of that person, of a financial, monetary or economic nature, or to which a monetary value may be attributed; but does not include any interest held by a person in a unit trust or collective investment scheme in terms of the Collective Investment Schemes Act 45 of 2002, unless that person has direct control over the investment decisions of that fund or investment." Delport (59) adds that it is uncertain when the financial interest will be "material" and that it is also not clear whether "materiality must be evaluated in respect of the 'subject matter', or in respect of the position of the director". 
basis for believing, and did believe, that the decision was in the best interests of the company; and

(b) is entitled to rely on -

(i) the performance by any of the persons -

(aa) referred to in subsection (5); or

(bb) to whom the board may reasonably have delegated, formally or informally by course of conduct, the authority or duty to perform one or more of the board's functions that are delegable under applicable law; and

(ii) any information, opinions, recommendations, reports or statements, including financial statements and other financial data, prepared or presented by any of the persons specified in subsection (5)."

The "business judgment rule" was also explained as follows in Shuttleworth $v$ Cox Brothers and Company (Maidenhead) Limited: ${ }^{56}$

"As I understand him, the Master of the Rolls is contrasting the acts of those, who honestly endeavour to decide and to act for the benefit of the company as a whole, with the conduct of others who act with a view to the interest of some of the shareholders and against that of others. Now when persons, honestly endeavouring to decide what will be for the benefit of the company and to act accordingly, decide upon a particular course, then, provided there are grounds on which reasonable men could come to the same decision, it does not matter whether the court would or would not come to the same decision or a different decision. It is not the business of the court to manage the affairs of the company. That is for the shareholders and directors. The absence of any reasonable ground for deciding that a certain course of action is conducive to the benefit of the company may be a ground for finding lack of good faith or for finding that the shareholders, with the best motives, have not considered the matters which they ought to have considered. On either of these findings their decision might be set aside. But I should be sorry to see the court go beyond this and take upon itself the management of concerns which others may understand far better than the court does."

It is thus clear that directors cannot be held liable for mere errors in judgment as illustrated by Fisheries Development. ${ }^{58}$ it is imperative to remember that directors act in the best interest of the company and with the required care and skill. They must always take reasonably diligent steps to become informed about the matter at hand and although they are allowed to take risks, this cannot be done in a reckless fashion. It must also be remembered that the directors of a company should promote the interests and success of the company in the collective best interests of shareholders. ${ }^{59}$ This can also include employees, customers and suppliers as the circumstance requires. It should also be mentioned that the common-law "enlightened shareholder value" approach has not been changed by the Companies Act and that the statutory "business judgment rule" provides for the interests of the company, meaning that the company as an entity does not consist of stakeholders. However, cognisance must be taken of so-called

\footnotetext{
19272 KB 9 (CA).

Shuttleworth v Cox Brothers and Company (Maidenhead) Limited supra 23-24.

8 Fisheries Development Corporation of SA Ltd $v$ Jorgensen supra; see also McClennan 2009 TSAR 186; and Meskin et al 462.

59 DTI Policy Paper 23.
} 
"stakeholder-inclusive approach"60 in King III which recognises the stakeholders of a company as important role players in the promotion of corporate governance principles. When exercising their duties, directors should also take note of the ethics of governance in terms of which the board's decisions and actions are underpinned by the following four basic values of good corporate governance, namely: ${ }^{61}$ responsibility, ${ }^{62}$ accountability, ${ }^{63}$ fairness, ${ }^{64}$ and transparency. ${ }^{65}$ The ethics of governance requires that a director of a company should be faithful to the ethical values of corporate governance. In the capacity of a steward, a director must act with responsibility, accountability, fairness and transparency. Directors therefore have the following five moral duties, namely, ${ }^{66}$ conscience, ${ }^{67}$ care,${ }^{68}$ competence, ${ }^{69}$ commitment, ${ }^{70}$ and courage. ${ }^{71}$

The Companies Act's provisions pertaining to the duties of directors are a semi- or quasi-codification of their common-law duties. ${ }^{72}$ This semicodification is welcomed because directors will have a better understanding what their duties are. ${ }^{73}$ Where the Companies Act is silent on certain issues

60 See also King II 19 par 41 where the Committee said that "successful governance in the world in the 21st century requires companies to adopt an inclusive and not exclusive approach. The company must be open to institutional activism and there must be greater emphasis on sustainable or non-financial aspects of its performance. Boards must apply the test of fairness, accountability, responsibility and transparency to all acts or omissions and be accountable to the company but also responsive and responsible towards the company's identified stakeholders. The correct balance between conformance with governance principles and performance in an entrepreneurial market economy must be found, but this will be specific to each company".

61 King III 56 par 33.

62 The board must act in a responsible manner when they deal with the assets of the company and they should also be willing to take corrective actions to keep the company on its strategic path.

63 Decisions and actions of the board should be justified to shareholders and other stakeholders when they are required to do so.

64 The board has the responsibility to ensure that when they act or decisions are made that fair consideration is given to the interests of all stakeholders of the company.

65 When they disclose information to stakeholders they must do so in a manner that will enable the stakeholders to make an informed analysis of the company's performance.

66 King III 56-57 par 34.

67 Directors should avoid conflict of interests by acting with intellectual honesty in the best interest of the company and all its stakeholders in accordance with the enlightened shareholder value approach. They should also apply independence of mind to ensure that the best interest of the company and its stakeholders is served.

68 Directors should devote serious attention to the affairs of the company and acquire relevant information that is required for exercising effective control and providing innovative direction to the company.

69 The knowledge and skills required for the effective governance of the company. Continued development of this competence should take place and the willingness to be regularly reviewed is a prerequisite for ensuring competence.

70 Diligence should be at the order of the day when performing directors' duties and sufficient time should be devoted to company affairs. Effort needs to be put into ensuring company performance and conformance.

71 Directors should have the courage to take the risks associated with directing and controlling a successful sustainable enterprise. In addition, directors should have the courage to act with integrity in all board decisions and activities.

72 McLennan 2009 TSAR 184.

73 Esser (Unpublished Doctoral Thesis 2008) 298. 
the common law will still apply ${ }^{74}$ and thus ensure that directors' duties remain flexible and capable of development. ${ }^{75}$ It must also be noted that according to the traditionalist view the common-law duties and liabilities of directors are adequately dealt with and that each matter should be dealt with on a case-by-case basis. The traditionalists were also of the view that if a codification in fact takes place it will result in the duties becoming superfluous. ${ }^{76}$ It must, however, be noted that directors possessed virtually unlimited powers under a traditionalist regime. ${ }^{77}$ However, according to the modernistic view the common-law standards are too modest and reflect outdated economic and social philosophies. ${ }^{78}$ Owing to the fact that South African companies are becoming more relevant in international trade, higher standards need to be imposed on directors when exercising their duties. The Companies Act is in fact a more modernistic approach to the traditionalist approach that was followed earlier. The non-compliance with the duties of directors is, however, a very important issue because failure to comply with their duties towards the stakeholders of the company will result in the directors being held liable. ${ }^{79}$ Section $77(2)$ (a) of the Companies Act provides that a director of a company may be held liable in accordance with the principles of the common law relating to breach of a fiduciary duty. This liability is for any loss, damages or costs sustained by the company as a consequence of any breach by the director of a duty by him (i) to disclose a personal financial interest; ${ }^{80}$ (ii) to avoid a conflict of interest: ${ }^{81}$ and (iii) to act in good and for proper purpose, or in the best interests of the company. ${ }^{82}$ According to Delport ${ }^{83}$ the liability of the director "for any benefit irrespective of the damage to the company" is apparently not covered by section 77(2)(a) and it is "not clear whether the common law will apply in this regard" Section $77(2)$ (b) further provides that liability of a director can take place in accordance with the principles of the common law relating to delict for any loss, damages or costs sustained by the company as a consequence of any breach by the director of (i) a duty to act with the required degree of care, skill and diligence; ${ }^{85}$ (ii) any provision of this Act not otherwise mentioned in this section; or (iii) any provision of the company's Memorandum of Incorporation. ${ }^{86}$ Cognisance must be taken of the very important section

74 Davis et al 16.

75 Esser (Unpublished Doctoral Thesis 2008) 298.

76 Bekink 2008 SA Merc LJ 115.

77 Mongalo "The Emergence of Corporate Governance as a Fundamental Research Topic in South Africa" 2003 SALJ 181.

78 See Bekink 2008 SA Merc LJ 115.

79 Cyberscene Ltd $v$ i-Kiosk Internet and Information (Pty) Ltd supra 820j where the court held that the liability for breach of a director's fiduciary duty is not delictual, but "sui generis".

$80 \mathrm{~S} 75$ of the Companies Act.

$81 \mathrm{~S} 76(2)$.

82 S 76(3)(a)-(b). This provision will be applicable except where the business judgment rule in terms of $\mathrm{s} 76(4)(\mathrm{a})$ is applicable.

83 Delport 63.

84 See Regal (Hastings) Ltd v Gulliver [1967] 2 AC 134 (HL); and Symington v Pretoria-Oos Privaat Hospitaal Bedryfs (Pty) Ltd [2005] 4 All SA 403 SCA.

$85 \mathrm{~S} 76(3)(\mathrm{c})$ of the Companies Act.

86 This provision will be applicable except where the business judgment rule in terms of $\mathrm{s}$ $76(4)(a)$ is applicable. 
218(2) which provides that any person who contravenes any provision of the Act is liable to any other person for any loss or damage suffered by that person as a result of that contravention. This means that although the statutory fiduciary duties exist between the directors and the company ${ }^{87}$ and not, for example, as regards employees, that employees can hold directors liable for breach of their duties if they have suffered losses because of such breach. It must also be mentioned that if a director, for example, fails to maintain unfettered discretion the common law will apply seeing that the Companies Act does not contain a provision to this effect hence section 218(2) will not be applicable. The cause of action in this instance will be sui generis based on breach of trust.

It must also be noted that the Companies Act not only introduces new provisions necessary for the creation of harmonisation with other legislation such as the Securities Services Act but also provides for a statutory code of conduct for directors. ${ }^{89}$ It is clear from the above that the Companies Act and King III are addressing the interests of stakeholders in companies. This is done by specifically outlining the fact that directors should act in the sole interests of the company as a whole and that the duties of good faith and care, skill and diligence should be applied in doing so. The fact that these duties are now legislated and that a code of conduct has been created are welcome moves in the right direction. This seems to amount to a codification and extension of the common-law duties of directors. These moves were necessitated due to the shortcomings of the Companies Act 61 of 1973 and the lack of proper legislation of corporate governance principles. This is also an important step towards the move away from what might be perceived as a limited form of protection to a much wider form of protection that is inclusive of all stakeholders of the company.

\section{CONCLUSION}

Good management is a critical factor in any developed or developing country for sound "corporate and economic development". In the context of corporate governance South Africa is sui generis in Africa. ${ }^{90}$ It remains to be seen whether the Companies Act will address the shortcomings of the Companies Act 61 of 1973 but it is definitely a step in the right direction. In addition to this the promotion of corporate governance in King III and other complementing legislation is definitely show-casing the importance to legislate this issue. The step towards a stakeholder-inclusive approach also highlights the importance of not only the shareholders of a company but also the importance of other stakeholders such as employees, suppliers et cetera. The common-law and statutory fiduciary duties and duties of care, skill and diligence thus form the cornerstone of corporate governance development in South Africa. The Companies Act and King III also address

87 Greaves v Barnard 20072 SA 593 (C) 598b reaffirmed that directors owe fiduciary duties to the company and must act in the company's best interests. The court acknowledged that the company is the beneficiary of these duties.

88 See Robinson v Randfontein Estates Gold Mining Co Ltd 1921 AD 168.

89 Davis et al 102.

90 Aka 291. 
an important issue regarding the duties of directors. The enhancement and semi-codification of their common-law duties are now legislated and the standards of conduct are also addressed. It might seem that the legislator is trying to over-legislate the issues concerning the duties of directors and their accountability, but it must be remembered that this is a necessary measure especially taking into account that the stakeholder-inclusive approach provides a much wider protection than what was provided for under the previous dispensation. It must also be remembered that globalisation and developments in national and international credit and consumer protection law, labour law, competition law, discrimination law et cetera have outdated the applicability of the Companies Act 61 of 1973.

In line with the corporate governance principles the following universal truth must be emphasised:

"Individuals today are the indirect providers of capital. They are consumers and, as citizens, are concerned about the sustainability of our planet. Those who prepare integrated reports have to give the readers the forward-looking information they want. It is one of the most important mechanisms a company can use to earn and maintain the trust and confidence of its stakeholders. Today's stakeholders also want assurance on the quality of this forwardlooking information." 